\title{
Linguistic Trends among Young Sindhi Community Members in Karachi
}

\author{
Muhammad Hassan Abbasi \\ Department of Humanities, NED University of Engineering \& Technology, Karachi, Pakistan \\ Maya Khemlani David \\ Honorary Professor, Asia-Europe Institute, University of Malaya, Kuala Lumpur, Malaysia \\ Sajida Zaki \\ Department of Humanities, NED University of Engineering \& Technology, Karachi, Pakistan
}

\begin{abstract}
Sindh is a multilingual province with Sindhi as its official language (Abbasi, 2017) and Sindhi is the third most common language spoken in Pakistan. (Census, 2017). However, in the cities of the Sindh province, Urdu the national language, is widely spoken is in constant competition with other regional languages (Ali, 2017). Due to rapid urbanization and modernization, different communities are shifting to cities for better economic conditions. This study explores linguistic trends by investigating the language used by young Sindhi speakers in the city of Karachi and has used Fishman's domain model (1971). The domain identifies the use of language in different settings between a range of interlocutors and the purpose of communication between interlocutors. The methodology used to collect data was both questionnaire and observation. The results indicates that the use of other languages-Urdu and English is often noted in various domains. Even within the home domain Sindhi speakers are frequently using 'the other tongue'. This study encourages researchers to study language choices in contact situations in the urban cities of Pakistan.
\end{abstract}

Key words: $\quad$ Linguistic Trends, Community Domain, Language Choices, Karachi, Sindhi, Pakistan

\section{Introduction}

Language is the core part of the knowledge system in any community; it represents the cultural and linguistic diversity of a speech community (Abbasi, 2017). Globalization has a great influence on languages and English is today an important international language.

Pakistan is a multilingual state with nine major languages (as reported in the Census-2017) and sixty five other minority languages (Rahman, 2006). English is the Co-official language used in different domains of power and education, while Urdu is its national and official language (Article 251 of the Constitution of Islamic Republic of Pakistan). Urdu is the most widely understood language and medium of interaction in the urban areas, and is also used by other ethnic groups as it has become an identity marker for a Pakistani. The Sindhi language which is used by about 14.1 percentage of the total population in Pakistan is not a national language.

Karachi, the provincial capital of Sindh is known as the hub for linguistic and cultural diversity. Many diverse speech communities reside within the province. They speak Balochi, Dhatki, Memoni, Punjabi, Pashtoo, Sindhi, Saraiki and many northern languages. However, only nine languages were included in the Census-2017 survey and the other minority languages were included in the 'other language' column.

Urdu is the dominant language in the city, and is the national and official language of Pakistan (Rahman, 2002).It is used in the education work and media domains. Minority language speakers, migrating from their home-towns to Karachi have to learn and acquire Urdu lfor communication (Ali, 2010; 2015 \& 2017). Similar findings were reported by Nazir, Aftab and Saeed (2013); Nawaz, Umer, Anjum and Ramzan (2012) and Mansoor (1993) showed Punjabi speakers shifting to Urdu and English in urban areas due to societal, economic and cultural reasons. Ali (2015 \& 2017) explored the language choices of Balti, Brushaski, Shina and Khowar language speakers, who are living away from their home town and are living in Karachi. The findings showed that the mother tongue users mainly use the mainstream language (Urdu \& English) in a majority of the domains while indigenous languages have been reduced to the home domain that too only for those who are living with their families in Karachi. A similar study was conducted by Abbasi and Aftab (2019) on Dhatki language spoken in the eastern part of Sindh and in some parts of India. The linguistic choices of the young Dhatki speakers were explored and it was disclosed that they are shifting towards 


\section{Yinternational Research Journal}

p-ISSN 2202-2821 e-ISSN 1839-6518 (Australian ISSN Agency)

Sindhi, Urdu \& English and most of them were also eager to learn Chinese due to Chinese businesses in Pakistan. These studies in Karachi reveal that minority language speakers despite having a positive attitude towards their heritage language, tend to shift to more dominant powerful languages in the city.

Linguists claim that the Sindhi language is now used less in cities; especially Karachi (Rahman, 2002), as the Sindhi speaking population only makes up 10 percent of the total population of Karachi (Census, 2017).A number of studies have been conducted on the Sindhi Hindu diaspora (Daswani \& Parchani, 1978; David, 1999, 2001a, 2001b, 2003, 2017; Detaramani \& Lock, 2003; Dewan 1987 \& Ivengar, 2013) and the only study on the Sindh speakers in their home bound areas in Pakistan was conducted by David, Mumtaz and Baloch, 2017 but did not include the urban areas. The study by David et.al (2017) on Sindhi speakers used a questionnaire to elicit information from 320 male and female participants from 16 districts of Sindh province and examined language use across the generations. As the Sindhis apart from external diaspora are migrating internally as well we focus in this research on the young generation of Sindhis in the city of Karachi who are migrating to cities for education and workplace opportunities.

\section{Objective of the Study}

The objective of this study is to explore the patterns of language choice among young Sindhi community members in different domains who are working and studying in Karachi.

\section{Literature Review}

Language choice varies from one situation to another, from one domain to another and also depends on the objective of the discourse and who is speaking to whom. The major domains that Fishman identified are family, friendship, religion, education and employment (Scotton, 2006)

Language maintenance is an important phenomenon in the presence of dominant languages. Fase, Jasport \& Kroon (1992) define language maintenance as relating to the continuing use and proficiency in one's mother tongue or heritage language.

Anthonissen (2009) defines language shift as a process which occurs when a community gives up a language completely in favor of another. Umrani \& Memon (2016) take a similar position especially when one is in a language contact situation. As far back as 1991 Fishman (1991) defined language shift ad the non-use of a heritage language by the users, with fewer speakers, readers, writers and even reduced proficiency in every generation.
Vol. 10 No. 022020

82801002202003

Language shift and maintenance are related or linked to a set of factors such as socio-economic conditions in a society, migration into or out of regional areas, institutional support for the language, status of the language, and language attitude. (Appel \& Muysken, 1987; David, Naji, \& Kaur 2003; Dorian 1980; Fasold, 1984; Gal, 1979; Mukherjee 2003). David and Dealwis (2008) listed urbanization, increased mobility, and education as macro level language shift factors.

Language shift can occur across generations. If elders speak the traditional language but their grandchildren do not, then language shift has occurred (Fasold, 1984). Most of the studies conducted across three generations have reported that language shift tends to occur within the young generation. (David, 1996; Hoffman \& Cais, 1984; Romaine, 1994). However, Zaid, Mee and Hei (2012), noted that cross-cultural marriages in Malaysia can also result in language shift.

David's (1999) study in Malaysia reported a shift away from the heritage language Sindhi and a shift to English \& Malay language. A similar finding was also reported among the Sindhis of Singapore (David, 2000) where mixed discourse appears to be the new language of the community who have to accommodate to the linguistic preferences of both young and old community members. Ivengar (2013) also explored the Sindhi community in an urban area in India i.e. Pune to determine the perceptions of the young Sindhis. The findings showed that all the informants rated their need for, exposure and emotional attachment to the Sindhi language as low and had poor competence in the Sindhi language.

However Sindhis in the province of Sindh David et al (2017) showed that Sindhi enjoys higher ethnolinguistic vitality. They usually maintain their language in different domains and have sentimental affiliation with the language as part of their cultural identity. However, this study focuses on the language choice and use patterns among young Sindhi community members in Karachi.

\section{Theoretical Model}

Most of the studied on Language shift and maintenance incorporate Fishman's domain concept to measure the degree of language shift/maintenance by focusing on the language choice and use in different domains. Fishman's major theoretical foundations were in the issue of 'who speaks what language and to whom and when'. It relied on the location, topic and participants. Fishman's (1971) model of language shift and maintenance specified domains for observing language use. The domains in this study are expanded. Similarly, for validity of the data reported, observations are also made as part of the model. The participant observation 
was carried out in the homes, social events and gatherings for 10 hours and notes were taken (See Figure 1).

\section{Methodology}

In sociolinguistic studies, researchers have largely adopted the qualitative case study research design for obtaining data, as it provides comprehensive data. (Ali 2015 \& Ali, 2017). Case studies are beneficial and reliable as they provide an insight view of a participant, "to understand the complexity and dynamic nature of the particular entity and to discover systematic connections among experience, behavior and relevant features of the context" (Johnson, 1992, p. 84). In this study, multiple instrumental cases were studied as Duff (2008) believes that in studies with many participants, "case studies may be provided to personalize and illustrate profiles of particular members within a studied group" (p. 43-44). Multiple instrumental case study was specifically chosen because the focus of this research was a minority speaking linguistic community in the city of Karachi whose mother tongue is Sindhi and their exposure to multilingual language contact situation in the city.

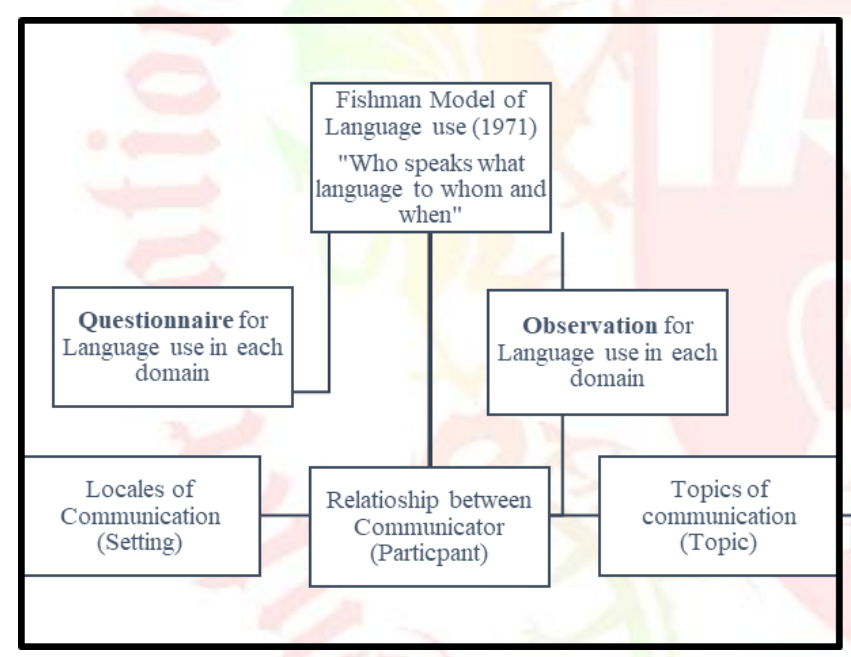

Figure 1 Fishman Model of Language Use, 1971 (Modified)

\section{A. Research Site}

In qualitative studies, the selection and access to the research participants is an important stage. The research site selected for this study was a public sector university situated in the urban area of Karachi. Students from different ethnographic groups are the essential part of the university resulting in a rich linguistic diversity. Since, the population of the university is diverse, it makes it a perfect research site for any study on multilingualism and sociolinguistics. Many Sindhi speakers are enrolled in the university, as they have reserve seats from Hyderabad, Mirphurkhas, Larkana Sindh Board. Furthermore, the public sector university is a fairly leading institute in the city, where students from diverse linguistic backgrounds are enrolled. For the current study members of Sindhi community (native Sindhi-speaking students) were selected who are enrolled in different departments in the university.

\section{B. Participants and Sampling}

The population for this study included members of the Sindhi community who live in Karachi. The target population was young native Sindhi undergraduates studying in a public university in Karachi.

Purposive sampling was used to elicit comprehensive information from the participants (Cohen et al., 2013; SavinBadin \& Major, 2013). The data was collected from young native Sindhi-speakers who have been exposed to a non-native environment for a period more than five years, and who were residing with their parents in Karachi.

Thirty male and female students were asked to fill the sociolinguistic profile; which consisted of demographic information, language biography and language use data (Charmaz, 2006). The sample size of thirty was sufficient because similar perspectives and responses from the participants were being obtained. Therefore further participants were not made part of the study and thirty participants' data was considered to be reliable. In order to validate the findings of the sociolinguistic questionnaire, five participants were selected for observation based on their accessibility and willingness (Creswell, 2012).

\section{Research tools}

In the present qualitative case study, the information about language use in different domains was essential to obtain. For this purpose, the information was collected through a sociolinguistic questionnaire. The questionnaire provided basic demographic language biography and language use in each domain, with different interlocutors and with different topics.

The sociolinguistic questionnaire used in this study was adapted from Khan (2014). The domains of language use Fishman (1971), Khan (2014) and Ali (2015) included in their studies like home, neighborhood, market, friends, classroom, canteen, workplace and hostel, were used.. Moreover, other domains of language use like social protests, restaurants, gatherings and social media, and language use with interlocutors like paternal and maternal parents, cousins and relatives, father, mother, siblings and friends were also included in the questionnaire. Furthermore, the topic of conversation with the interlocutor were also included. These variables had to be included as language shift is not measured only by analyzing language choice in different domains or language preference with a range of interlocutors but the topic 


\section{Yinternational Research Jourmal}

p-ISSN 2202-2821 e-ISSN 1839-6518 (Australian ISSN Agency)

of the interaction with the interlocutor also determines the language used.

As the research is qualitative case study, observation appears to be a useful tool. The participants can be easily observed in terms of language use with interlocutors and in different domains. Participant observation was conducted using a technique of shadowing (Umrani, 2015). Through shadow observation one of the writers was able to seek the answers to additional questions (McDonald, 2005).

The site selected for observation has to be a natural setting and one that is accessible to the researchers and the participants. Two participants were observed in their homes for four hours, after consent was obtained. Two of the participants were observed at the wedding of a cousin of one of the participants four participants attended a social event 'Sindhi Literature Festival' The four participants arrived at different intervals and were observed for three hours each. Hence, the participants were observed for ten hours in three different settings. The observation validated the findings reported in the questionnaire.

A questionnaire is an essential tool to obtain data for language use patterns, however in order to cross-validate the information reported by the respondents, observations are necessary to check the reliability and validity of the responses. Hence, the present study uses sociolinguistic questionnaire to elicit information about language use and observation to validate the information obtained from the questionnaire.

\section{Data Analysis}

The data from the questionnaire was used to obtain frequency and percentage of language choices use in different domains with different interlocutors focusing on different topics. Observations were made to check whether the responses given by the respondents in the questionnaire reflect authentic interactions.

\section{Findings}

The first section inquired about the basic demographic information, while the second section inquired about language proficiency that included speaking, reading, listening and writing; it also enquired if code-switching occurred and if so with what other languages. The third section was developed according to Fishman's model (1971) which focused on language used in different settings, determining language used with the interlocutor and language used for each topic with the interlocutor
Vol. 10 No. 022020

82801002202003

\section{A. Speaking}

The analysis of the items shows interesting data that despite being native Sindhi speakers only $40 \%$ of the speakers 'always speak' in Sindhi; while $32 \%$ do not use it frequently. About $28 \%$ of the participants said they 'never use/speak' the language in the urban setting.

During observation at home, it was observed that speakers frequently code-switch from one language to the other. When the participant spoke with their parents most of the phrases were in Urdu

\section{B. Switching to other language}

Similarly, the participants were inquired about switching to other languages in the multilingual urban setting. Almost $68 \%$ of the participants reported to switch to other language. Few (12\%) said that they occasionally switched, while $12 \%$ rarely switched to another language. However, $8 \%$ of the speakers said that they never switched to other languages and only communicated in their own native Sindhi language. While observing one of the participants, it was seen that within the family, code-switching was the preferred medium for communication for different topics of communication.

\section{Summary of Basic Demography}

The young Sindhi respondents have no competence in reading (40\% rarely and $40 \%$ never ) and writing (24\% rarely and $40 \%$ never); and the majority of the participants reported that they rarely use reading and writing skills in their mother tongue ( see Figure 2 which provides a brief summary of the language biography). Additionally, the participants rarely listen to the language (28\% rarely and $32 \%$ never). The overall results signify that the Sindhi language has been reduced to spoken discourse (40\% always use it) but within it switching to the other language is quite common as $68 \%$ reported to switching to other languages. The young Sindhi participants are not reading, writing, listening and even watching the folk tradition (40\% rarely and 40 never) in the native language. (See figure. 02 for summary of language biography.)

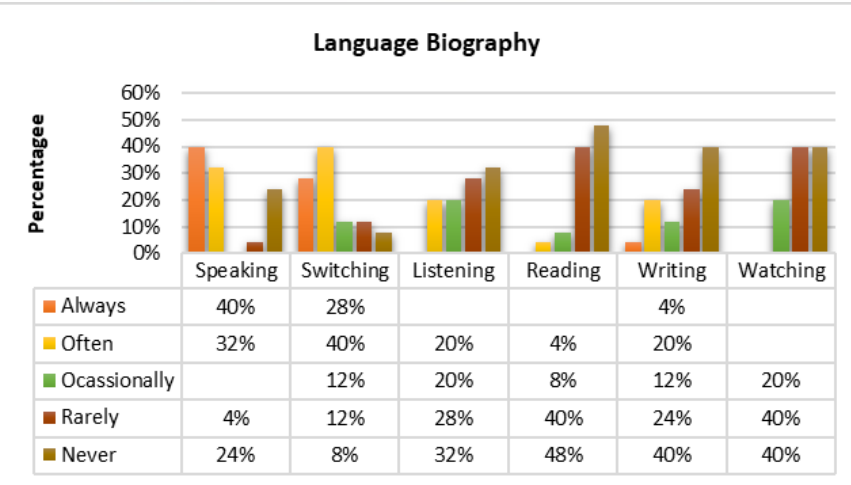

Figure 2 Language Biography 


\section{Language use in different domains}

Home is an important setting where a language develops and frequent interaction in the mother tongue is possible. Data analysis shows interesting results regarding the Sindhi language used by the native speakers in their home domain. A total of $52 \%$ of the participants reported that they used Sindhi in their home most often, while $40 \%$ reported that they used Urdu in their home. However, $8 \%$ reported use of English.

In the urban multilingual context, analysis show that nearly $84 \%$ of the participants reported that they used Urdu while nearly $16 \%$ said that they used Sindhi when interacting with the neighbors.

Use of language in the social gatherings also pre-determines the societal value of a language. Analysis shows that almost 92\% used Urdu in social gatherings while merely $4 \%$ used Sindhi and English simultaneously when gathered for an event. During the literary festival and wedding, it was observed that the participants were using Urdu frequently for different purposes, even on occasions where both the participants were native Sindhi speakers.

Languages are also shaped by cultural and religious beliefs, therefore religious events are a strong indicator of language maintenance. (David et al, 2017). The results however show that $96 \%$ of the Sindhi participants said that they used Urdu while only $4 \%$ said that they used their mother tongue when praying.

\section{E. Language use with the interlocutor}

The second part of Section III of the questionnaire inquired about the language used with the interlocutor. Figure 03 shows that the young Sindhi speakers use Urdu with shopkeepers, colleagues and friends. However, with maternal/paternal uncles, aunts, cousins and relatives Urdu is used although not as much as Sindhi. With the older generation, Sindhi is maintained, but the trends are changing as about $32 \%$ and $24 \%$ of participants are using Urdu frequently with interlocutors. It was observed that during the literary festival participants used Urdu for communicating with their young relatives, while a code-mixed variety was used when communicating with close relatives.

\section{F. Language use for different Topics of communication between interlocutors}

\section{Language use for different topics with father}

The analysis shows that young Sindhi speakers preferred to use English for discussion on topics related to academia - in this case academic issues, and book discussion. Also when discussing entertainment topics like travelling and movie plans English is the most frequent language used. As for discussions on shopping, health and media Urdu is frequently used. Sindhi is mostly related to topics like gossip, political talk, nature, informal discussion and talk on food as shown in the Table 1.

Table 1: Language use for different topics with Father

\begin{tabular}{lccl}
\hline Topic & Sindhi & Urdu & English \\
\hline Gossip & $60 \%$ & $36 \%$ & $04 \%$ \\
Shopping discussion & $24 \%$ & $76 \%$ & $04 \%$ \\
Political views & $52 \%$ & $28 \%$ & $20 \%$ \\
Academic issues & $04 \%$ & $28 \%$ & $68 \%$ \\
Health & $24 \%$ & $60 \%$ & $16 \%$ \\
Media talks & $08 \%$ & $64 \%$ & $28 \%$ \\
Academic discussions & & $40 \%$ & $60 \%$ \\
Informal discussion & $68 \%$ & $32 \%$ & \\
Kitchen/ Food talk & $56 \%$ & $34 \%$ & \\
Movie Plan & $08 \%$ & $32 \%$ & $60 \%$
\end{tabular}

Language use with Interlocuters

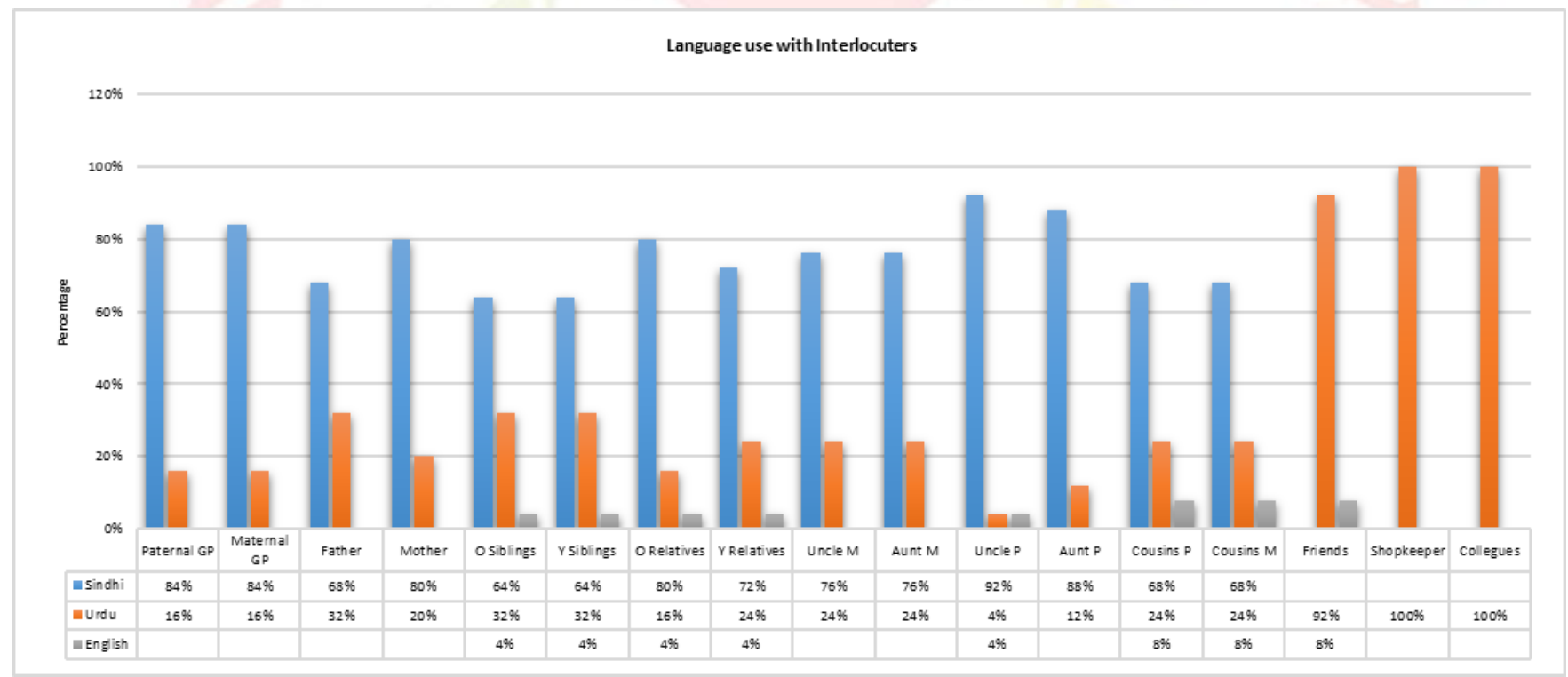

www.irj.iars.info

www.researth.iars.info/index.php/curie 


$\begin{array}{llll}\text { Travelling Plan } & 12 \% & 24 & 64 \% \\ \text { Book Discussion } & & 24 & 76 \%\end{array}$

\section{Language use for different topics with mother}

In the case of mother, the language choice for each topic differs as Sindhi is the most frequent language as shown in the Table 2 for various topics of discourse like shopping, gossip, health, media talk etc. However there is little use of English with the mother even for academic issues and academic discussion.

Table 2 : Language use for different topics with Mother

\begin{tabular}{lccl}
\hline Topic & Sindhi & Urdu & English \\
\hline Gossip & 72 & $28 \%$ & \\
Shopping discussion & $40 \%$ & $60 \%$ & \\
Political views & $78 \%$ & $32 \%$ & \\
Academic issues & $60 \%$ & $32 \%$ & $08 \%$ \\
Health & $56 \%$ & $44 \%$ & \\
Media talks & $72 \%$ & $28 \%$ & \\
Academic discussions $56 \%$ & $36 \%$ & $08 \%$ \\
Informal discussion & $72 \%$ & $28 \%$ & \\
Kitchen/ Food talk & $68 \%$ & $32 \%$ & \\
Movie Plan & $68 \%$ & $32 \%$ & \\
Travelling Plan & $64 \%$ & $36 \%$ & \\
Book Discussion & $72 \%$ & $28 \%$ & \\
\hline
\end{tabular}

\section{Language used for different topics with siblings}

Similarly, young Sindhi speakers used English for communication on topics like media, academic issues, and book discussions with siblings more than Urdu as shown in Table 3. However, for the rest of the topics Urdu was preferred more than English; and Sindhi was used less frequently by the participants for communication with siblings. Therefore, the dynamics of language use in the home domain with the siblings is changing.

Table 3: Language use for different topics with Siblings

\begin{tabular}{lccc}
\hline Topic & Sindhi & Urdu & English \\
\hline Gossip & $20 \%$ & $40 \%$ & $40 \%$ \\
Shopping & $36 \%$ & $36 \%$ & $28 \%$ \\
discussion & & & \\
Political views & $28 \%$ & $44 \%$ & $28 \%$ \\
Academic issues & $16 \%$ & $40 \%$ & $44 \%$ \\
Health & $12 \%$ & $48 \%$ & $40 \%$ \\
Media talks & $20 \%$ & $20 \%$ & $60 \%$
\end{tabular}

$\begin{array}{lccc}\begin{array}{l}\text { Academic } \\ \text { discussions }\end{array} & 16 \% & 40 \% & 44 \% \\ \begin{array}{l}\text { Informal } \\ \text { discussion }\end{array} & 12 \% & 48 \% & 40 \% \\ \begin{array}{l}\text { Kitchen/ Food } \\ \text { talk }\end{array} & 20 \% & 40 \% & 40 \% \\ \begin{array}{l}\text { Movie Plan } \\ \text { Travelling Plan }\end{array} & 16 \% & 44 \% & 40 \% \\ \text { Book Discussion } & 20 \% & 48 \% & 32 \% \\ & 08 \% & 32 \% & 60 \%\end{array}$

4. Language used for different topics of communication with cousins and relatives

The language preferred with the first cousins during different topics of communication was mostly Sindh and Urdu. Gossip (68\% Sindhi and 32\% Urdu), Shopping discussion (64\% Sindhi and $36 \%$ Urdu), political views (60\% Sindhi and $40 \%$ Urdu), informal discussion (60\% Sindhi and 40\% Urdu), kitchen/food talk (60\% Sindhi and 40\% Urdu). For discussion on topics like health (48\% Sindhi, $40 \%$ Urdu and 12\% English) was used; media talks (52\% Sindhi, 36\% Urdu and 12\% English) was used. While for discussion on topics related to academia and entertainment; English was preferred more for academic issues (English 44\%, Urdu 36\% and Sindhi 20\%), academic discussion (40\% English and Urdu each and 20\% Sindhi); book discussion (40\% English and Urdu each and $20 \%$ Sindhi) and movie plan (40\% English and Urdu each and $20 \%$ Sindhi). However for travelling plans it was $30 \%$ English, $42 \%$ Urdu and 28\% Sindhi.

Table 4: Language use for different topics with cousins and relatives

\begin{tabular}{lccc} 
Topic & Sindhi & Urdu & English \\
\hline Gossip & $60 \%$ & $40 \%$ & \\
$\begin{array}{l}\text { Shopping } \\
\text { discussion }\end{array}$ & $60 \%$ & $40 \%$ & \\
$\begin{array}{l}\text { Political views } \\
\text { Academic }\end{array}$ & $56 \%$ & $44 \%$ & \\
issues & $20 \%$ & $40 \%$ & $40 \%$ \\
$\begin{array}{l}\text { Health } \\
\text { Media talks }\end{array}$ & $40 \%$ & $60 \%$ & \\
Academic & $20 \%$ & $40 \%$ & $40 \%$ \\
discussions & & & \\
Informal & $60 \%$ & $40 \%$ & \\
discussion & & & \\
Kitchen/ Food & $60 \%$ & $40 \%$ & \\
talk & & & \\
Movie Plan & $60 \%$ & $40 \%$ & \\
Travelling & $60 \%$ & $40 \%$ & \\
Plan & & & \\
Book & $20 \%$ & $40 \%$ & \\
\hline
\end{tabular}




\section{Yinternational Research Journal}

p-ISSN 2202-2821 e-ISSN 1839-6518 (Australian ISSN Agency)

Relatives also play a critical role in the choice of language during communication. However, with most of the relatives Sindhi and Urdu was reported to be used more as shown in Table 4. In almost all of the topics $60 \%$ opted for Sindhi while $40 \%$ opted for Urdu. These topics ranged from gossip, shopping discussion, and kitchen/food talk. As for verse topics like health and media talks $60 \%$ used Urdu and 40\% Sindhi. However, with regard to academic issues, academic discussion and book discussion English was used more than Urdu and Sindhi. (40\% English, 40\% and 20\% Sindhi).

\section{G. Wedding and Literary Festival}

Wedding events and Sindhi Literature Festival held in the month of February was observed with the participants' consent. It was observed that the participant's followed the same patterns of language use as reported in the profile with shopkeepers, friends and cousins in both the events. Also, they frequently used English and Urdu with each other and codemixing patterns were also noted in their communication.

\section{Conclusion and Discussion:}

Figure 2 provides essential insights into the proficiency of speakers. This study reveals that Sindhi speakers in the urban domain have low competence in their mother tongue as $32 \%$ of them reported that they never receive language input in listening encounters, $88 \%$ of Sindhi speakers were not interested in reading in Sindhi language and $64 \%$ of them have never written in Sindhi and 12\% occasionally write. Only $40 \%$ of the Sindhi speakers speak the Sindhi language always while $28 \%$ (24\% never and 4\% rarely) use it. Ivengar (2003) also reported that Sindhi youth in urban area had poor competence in Sindhi.

Home domain is regarded as a major component for language contact and maintenance. The present study shows that there is shift towards English/Urdu (40\% Urdu and 8\% English) in the home domain. . In domains like neighborhood, social gatherings, religious domain and academic both Urdu and English are the preferred languages. Hence, the speakers have shifted in these domains from their mother tongue to Urdu and English.

Similarly, as identified by David (1999) the topic for communication is also vital in identifying language choice. The present study has shown patterns of language use in the home domain with father and siblings which are more in English and Urdu than Sindhi. However, with the mother, Sindhi language is retained. In this study, new patterns of language use among the siblings have emerged where Urdu and English is used more than Sindhi. The analysis of the present study shows that the Sindhi speakers are resorting to use Urdu and English with their siblings and even younger
Vol. 10 No. 022020 82801002202003

ones, as narrated by David (2000) in her study of the Sindhis in Singapore.

In the home domain participants used English for discussion on academic issues, movie and travelling plans. However for health topics, media talks and shopping discussion Urdu is used and Sindhi is retained for informal discussion, political views and gossip.

In conclusion Letsholo (2009) while exploring language use reported that the native speakers were not using their mother tongue even in the domains where mother tongue could be used; like speaking with parents and siblings with the same mother tongue.

It is clear that language policy of Pakistan affects the speech communities who adopt the majority language which also has a national status (Ali, $2015 \& 2017$ ). When the scenario in the home domain changes and shifts away from the dominant use of the heritage language there is bound to be a shift to a new language, in this case the national language, Urdu and the international language, which is also an official languageEnglish. This shift to Urdu and English seems to be facilitated by parents, siblings and community members. The present study shows that language shift is taking place in various domains where previously mother tongue was used.

\section{References}

[1]. Abbasi, M.H. (2017). "Language Shift among Third Generation Sindhi Speakers" presented at International Conference of Linguistic Association of Pakistan (ICLAP), Karachi.

[2]. Abbasi, M.H \& Aftab, M. (2019). "Mother tongue or other tongue? The case of Dhatki speakers". Balochistan Journal of Linguistics. 7.81-92.

[3]. Ali, S. S. (2010). "Language Attitudes of Educated Pakistanis with Special Reference to Urdu Punjabi, and English". An Unpublished M. Phil Thesis. Department of English, University of Karachi.

[4]. Ali, S. S. (2015). "Minority Language Speakers' Journey from the Mother tongue to the other tongue: A case study". Kashmir Journal of language Research, 18(3). 65-81.

[5]. Ali, S. S. (2017). "Language Shift and Ethnolinguistic Vitality: a sociolinguistic study of Indigenous minority language speakers in Karachi”. (Phd Thesis, Department of English, University of Karachi).

[6]. Anthonissen, C. (2009). "Bilingualism and Language shift in Western Cape communities in 
Africa". Mehrsprachigkeit and Sprachenpolitik in Afrika, 32(5), 421-434.

[7]. Appel, R., \& Muysken, P. (1987). "Language Contact and Bilingualism". Amsterdam: Amsterdam University Press.

[8]. Census. (2017). "Census report of Pakistan". Islamabad: Population Census Organization Statistics Division. Government of Pakistan.

[9]. Charmaz, K. (2006). "Constructing Grounded Theory: A Practical Guide through Qualitative Analysis". London: Sage Publications.

[10]. Cohen, L., Manion, L., \& Morison, K. (2013). "Research methods in Education" (7th Ed.) Routledge.

[11]. Creswell, J. (2012). "Educational Research: Planning, Conducting, and Evaluating Quantitative and Qualitative Research". New York: Pearson

[12]. Daswani, C. J. and Parchani S. (1978) "Sociolinguistic Study of Indian Sindhi". Central Institute of Indian Studies. Mysore: CIIL

[13]. David, M. K (1996). "Mother-in-law and Daughter-in-law Relationships: A North/South Indian Perspective as Seen in Sindhi and Tamil Proverbs". Journal of the Malaysian Modern Language Association, 1, 73-80

[14]. David, M. K. (1999). "Language Shift among the Sindhis of Malaysia". South Pacific Journal of Psychology, 10(1), 61-67.

[15]. David, M. K. (2000). "The Sindhis of Singapore: Language Maintenance or Language Shift?" Migracijske Teme, 16(3), 271-288.

[16]. David, M. K. (2001a). "The Sindhis of Malaysia: A Sociolinguistic Account”. London: Asean

[17]. David, M. K. (2001b). "The Sindhis of London: Language Maintenance or Language Shift?" Migracijske I etnicke Teme, 3, 215-238.

[18]. David, M. K. (2003). "Reasons for Language Shift in Peninsular Malaysia”. In Ramlah, H. et al. (Eds), Investing in Innovation Humanities Social and Science (pp 111-114). Universiti Putra Malaysia Press, Serdang, Selangor, Malaysia.

[19]. David, M.K., Naji, I.M., \& Kaur, S. (2003). "Language Maintenance or Language shift among the Pubjabi Sikh Community in Malaysia".
International Journal of the Sociology of the language, 1(161), 1-24.

[20]. David, M.K., \& Dealwis, C. (2008) "Why shift? Focus on Sabah and Sarawak". Suvremena Linguistika, 34(66), 261-276.

[21]. David, M. K., Ali. M., \& Baloch, G. M. (2017). "Language Shift or maintenance: The Case of Sindhi Language in Pakistan". Language Problem \& Planning, 41(1), 26-45.

[22]. Dewan, R. (1987). Deethnisation: "A study of language and culture change in the Sindhi immigrant community of Metro Manila". Unpublished Ph.D. Thesis De la Salle University.

[23]. Duff, A.P. (2008). "Case Study Research in Applied Linguistics". New York: Lawrence Erlbaum Associates.

[24]. Fase, W., Jaspaert, K., \& Kroon, S. (1992). "Maintenance and loss of minority languages". (1st Ed.). John Benjamin's publishing.

[25]. Fasold, R. (1984). "The Sociolinguistics of society". Oxford: Blackwells.

[26]. Fishman, J. (1971). "Advances in the sociology of language". The Hague: Mouton.

[27]. Fishman, J. (1991) "Reversing Language Shift: Theory and Practice of Assistance to threatened languages”. Clevedon, UK: Multilingual Matters.

[28]. Gal, S. (1979). "Language Shift: Social determinants of language change in bilingual Austria". New York: Academia.

[29]. Hofman, J., \& Cais, J. (1984). “Children's attitudes to language maintenance and shift". International Journal of the Sociology of Language, 50, 147-153.

[30]. Iyengar, A. (2013). "Self-perceptions of heritage language shift among young Sindhis in Pune". Masters in Applied Linguistics, University of New England, Australia.

[31]. Johnson, D. M. (1992). "Approaches to research in second language learning”. New York: Longman.

[32]. Dumanig, F., M. K. David, L. A. (2020). Channa, and S. A. Manan. "Language Shift and Ethnic Identity: Focus on Malaysian Sindhis". IARS' International Research Journal, vol. 10, no. 1, Feb. 2020, DOI/URL: https://researth.iars.info/index.php/curie//article/view/92. 
[33]. Khan, R.K. (2014). “A Sociolinguistic Analysis of Classroom Discourse with Special Reference to Code-Switching". An Unpublished Ph.D. Thesis. Department of English, University of Karachi.

[34]. Letsholo, Rose. (2009). "Language maintenance or shift? Attitudes of Bakalanga youth towards their mother tongue". International Journal of Bilingual Education and Bilingualism, 12(5), 581-595.

[35]. McDonald, S. (2005). "Studying actions in context: A qualitative shadowing method for organizational research". Qualitative Research, 5(4), 455-474.

[36]. Mukeerjee, D. (2003). "Role of women in language maintenance and language shift. Focus on the Bengali Community in Malaysia”. International Journal of Sociology of the language. 161, 103-20.

[37]. Nawaz, S., Umer, A., Anjum, F., \& Ramzan, M. (2012). "Language Shift: An Analysis of Factors Involved in Language Shift". Global Journal of Human Social Science Linguistics \& Education, 12(10), 73-80.

[38]. Nazir, B., Aftab, U., \& Saeed, A. (2013). "Language Shift - The Case of Punjabi in Sargodha Region of Pakistan". Acta Linguistica Asiatica, 3(2), 41-59.

[39]. Rahman, T. (2002). "Language, Ideology and Power: Language Learning among the Muslims of Pakistan and North India". Oxford University Press: Karachi.

[40]. Rahman, T. (2006). "Language Policy, Multilingualism and Language Vitality in Pakistan”. In A. Saxena, \& L. Borin, (Eds.), Trends in Linguistics: Lesser-Known Languages of South Asia-Status and Policies (Case Studies and Applications of Information Technology (pp. 73104). Berlin and New York: Mouton de Gruyter.

[41]. Romaine, Suzane. (1994). "Language in society: An introduction to sociolinguistics". New York: Oxford University Press.

[42]. Savin-Baden, Maggi., \& Major, Calire Howell. (2013). "Qualitative Research: The essential guide to theory and practice". Routledge.

[43]. Scotton, Carol Myers. (2006). "Multiple Voices: An Introduction to Bilingualism". UK: Blackwell Publishing Ltd.

[44]. Umrani, Sumera. (2015). "Constructing, Negotiating and reconstructing English Language
Learner Identity: A Case Study of Public Sector University in Postcolonial Pakistan". Doctoral thesis. University of Edinburgh.

[45]. Umrani, Sumera. \& Memon, Natasha. (2016). "Language Shift and maintenance: A case study of a Pakistani Scottish Family". ELF Annual Research Journal, 18, 43-64.

[46]. Zaid, A. R. M., Mee, M. Y., \& Hei, K. C. (2012). "Language Choice of Malaysian Chindians. Language in India". 12(11), 440-46. Retrieved on 24th March 2015, from http://www.languageinindia.com/nov2012/kuangchi ndiansfinal.pdf. 